\title{
Proposal of Salmonella paratyphi sp. nov., nom. rev. and Request for an Opinion to conserve the specific epithet paratyphi in the binary combination Salmonella paratyphi as nomen epitheton conservandum
}

\author{
Takayuki Ezaki, Makoto Amano, Yoshiaki Kawamura and Eiko Yabuuchi
}

Author for correspondence: Takayuki Ezaki. Tel: +8158267 2240. Fax: +81582670156. e-mail: tezaki@cc.gifu-u.ac.jp

Department of Microbiology, Gifu University School of Medicine, 40 Tsukasamachi, Gifu 500-8705, Japan

\author{
We propose Salmonella paratyphi sp. nov., nom. rev., by raising Salmonella \\ choleraesuis subsp. choleraesuis serovar Paratyphi A to species status and \\ request an Opinion to include the specific epithet paratyphi in the binary \\ combination of Salmonella paratyphi in the list of epitheta specifica \\ conservanda.
}

Keywords: Salmonella paratyphi, nomen epitheton conservandum, serovar Paratyphi A

\section{INTRODUCTION}

Kelterborn (1967) described a case of enteric fever, resembling typhoid fever, whose blood culture yielded 'paracolonbacillus', which was first reported by Gwyn in 1898. Kayser (1902) isolated an organism from the blood of a patient suffering from a typhoid-fever-like disease and named it 'Bacterium paratyphi'. Soon after, Brion \& Kayser (1902) described the clinical features of the patients and the serological differentiation of 'Bacterium paratyphi' from 'Bacillus typhi'. Both 'Bacillus typhi' and 'Bacterium paratyphi' were later transferred to the genus Salmonella. Though Salmonella typhi (Schroeter 1886) Warren and Scott 1930 retained its nomenclatural position by being listed in the Approved Lists of Bacterial Names (Skerman et al., 1980), Salmonella paratyphi (Kayser 1902) Castellani and Chalmers 1919 was not included in the Approved Lists and lost its standing in nomenclature. Furthermore, the generic name 'Bacterium' was cited in the list of nomina generum rejicienda by Opinion 4 (revised) (Judicial Commission, 1954), thus 'Bacterium paratyphi' Kayser was recognized as a validly published illegitimate name according to Buchanan et al. (1966) and cannot be the basonym of Salmonella paratyphi (International Committee on Bacteriological Nomenclature, 1958; Lapage et al., 1975).

Kauffmann $(1960,1963)$ and Kauffmann \& Edwards (1952) divided species in the genus Salmonella into 'sub-genera' I, II, III and IV based on their biochemical characteristics. Strains which inhabit in the intestinal tract of warm-blooded animals were in 'sub-genus' I. Le Minor \& Rhode (1974) described eight types of Salmonella in 'sub-genus' I, e.g. 'Salmonella cholerae-suis' (sic), 'Salmonella hirschfeldii' (Salmonella paratyphi-C), Salmonella typhi, Salmonella paratyphi-A, 'Salmonella schottmuelleri', Salmonella typhimurium, Salmonella enteritidis and 'Salmonella gallinarum'. Four of these, ' $S$. hirschfeldii', S. paratyphi-A, 'S. schottmuelleri' and ' $S$. gallinarum' were excluded from the Approved Lists and lost their standing in nomenclature. According to Buchanan et al. (1966), S. paratyphi-A was not a validly published name according to Rule $14 \mathrm{a}(1)$ of the International Code of Nomenclature of Bacteria and Viruses (International Committee on Bacteriological Nomenclature, 1958). Rule 14a(1) reads, 'The name of a species is validly published only when its publication conforms to the following requirements. (1) It must be published as a binary combination consisting of a generic name followed by a single specific epithet.' Rule 14a(1) of the 1958 Code corresponds to Rule 30(2) of the revised Code (Lapage et al., 1975, 1992).

Le Minor \& Popoff (1982) and Le Minor et al. (1982) studied 88 Salmonella reference strains, including Kauffmann's 'sub-genera' I-IV (Kauffmann, 1966) together with the bongor group, and performed numerical analysis and DNA-DNA hybridization. They proposed $S$. choleraesuis as the type and only species of the genus and five new subspecies corresponding to the former 'sub-genera' I-IV and the bongor group. S. choleraesuis subsp. choleraesuis 
Table 1. DNA/DNA similarities among selected Salmonella strains

Hybridization was carried out at the temperature shown in $2 \times$ SSC containing $50 \%$ formamide using S. paratyphi NCTC $5702^{\mathrm{T}}$ DNA as label DNA. Similarity values are shown \pm SD. CV, coefficient of variation.

\begin{tabular}{|c|c|c|c|c|c|}
\hline \multirow[t]{2}{*}{ Organism* } & \multirow[t]{2}{*}{ Description } & \multicolumn{2}{|c|}{ Hybridization at $46^{\circ} \mathrm{C}$} & \multicolumn{2}{|c|}{ Hybridization at $36^{\circ} \mathrm{C}$} \\
\hline & & $\begin{array}{l}\text { Similarity } \\
\text { value }(\%)\end{array}$ & CV $(\%)$ & $\begin{array}{l}\text { Similarity } \\
\text { value }(\%)\end{array}$ & CV $(\%)$ \\
\hline S. paratyphi $\mathrm{NCTC} 5702^{\mathrm{T}}$ & Kauffmann 1939 & $100 \cdot 0 \pm 0 \cdot 0$ & $0 \cdot 0$ & $100 \cdot 0 \pm 0 \cdot 0$ & $0 \cdot 0$ \\
\hline S. paratyphi GIFU 3P-430 & Human clinical & $91 \cdot 1 \pm 2 \cdot 4$ & $2 \cdot 7$ & $96 \cdot 0 \pm 3 \cdot 8$ & $4 \cdot 0$ \\
\hline S. paratyphi NCTC 13 & Schottmueller 1920 & $86 \cdot 4 \pm 5 \cdot 2$ & $6 \cdot 0$ & $89 \cdot 2 \pm 5 \cdot 5$ & $6 \cdot 1$ \\
\hline S. paratyphi GIFU 3P-426 & Human clinical & $85 \cdot 9 \pm 2 \cdot 5$ & $2 \cdot 9$ & $93.9 \pm 3.6$ & $3 \cdot 9$ \\
\hline S. typhi ATCC $19430^{\mathrm{T}}(\mathrm{Ty} 2)$ & Type strain & $90 \cdot 6 \pm 0 \cdot 1$ & $0 \cdot 1$ & $93 \cdot 8 \pm 1 \cdot 6$ & $1 \cdot 7$ \\
\hline S. choleraesuis NCTC $5735^{\mathrm{T}}$ & Type strain & $85 \cdot 9 \pm 0 \cdot 8$ & $0 \cdot 9$ & $83 \cdot 3 \pm 1 \cdot 0$ & $1 \cdot 2$ \\
\hline S. enteritidis ATCC $13076^{\mathrm{T}}$ & Type strain & $81 \cdot 9 \pm 8 \cdot 4$ & $10 \cdot 3$ & $89 \cdot 7 \pm 11 \cdot 7$ & $13 \cdot 0$ \\
\hline S. typhimurium ATCC $13311^{\mathrm{T}}$ & Type strain & $78 \cdot 3 \pm 5 \cdot 6$ & $7 \cdot 1$ & $88 \cdot 5 \pm 8 \cdot 5$ & $9 \cdot 6$ \\
\hline Herring sperm DNA & & $0 \cdot 0 \pm 0 \cdot 0$ & - & $0 \cdot 0 \pm 0 \cdot 0$ & - \\
\hline
\end{tabular}

* GIFU 3P, Gifu University Level Three collection of human pathogens, Japan.

Table 2. Differential characteristics of S. paratyphi from other Salmonella species

\begin{tabular}{|c|c|c|c|c|c|c|}
\hline Characteristic & $\begin{array}{l}\text { S. choleraesuis } \\
\text { NCTC } 5735^{\mathrm{T}}\end{array}$ & $\begin{array}{l}\text { S. enteritidis } \\
\text { ATCC } 13076^{\mathrm{T}}\end{array}$ & $\begin{array}{c}\text { S. typhimurium } \\
\text { ATCC 13311 }^{\mathrm{T}}\end{array}$ & $\begin{array}{c}\text { S. typhi } \\
\text { ATCC 19430 }\end{array}$ & $\begin{array}{l}\text { S. paratyphi } \\
{\text { NCTC } 5702^{\mathrm{T}}}^{\text {NCT }}\end{array}$ & $\begin{array}{l}\text { S. paratyphi } \\
\text { (eight strains) }\end{array}$ \\
\hline \multicolumn{7}{|l|}{ Conventional tests } \\
\hline Lysine decarboxylase & + & + & + & + & - & - \\
\hline Ornithine decarboxylase & + & + & + & - & + & + \\
\hline $\mathrm{H}_{2} \mathrm{~S}$ on TSI agar & + & + & + & Weak & - & Weak or - \\
\hline Simmons' citrate & + & + & + & - & - & - \\
\hline Gas from glucose & + & + & + & - & + & + \\
\hline Antigenic formula & $6,7: c: 1,5$ & $1,9,12: \mathrm{g}, \mathrm{m}:-$ & $1,4,(5), 12: b: 1,2$ & $9,12, \mathrm{Vi}: \mathrm{d}:-$ & $1,2,12: \mathrm{a},-$ & $1,2,12: \mathrm{a},-$ \\
\hline \multicolumn{7}{|l|}{ API tests } \\
\hline D-Xylose & + & + & + & + & - & - \\
\hline Glycerol & - & - & + & + & + & - \\
\hline L-Arabinose & - & + & + & - & + & + \\
\hline L-Rhamnose & + & + & + & - & + & + \\
\hline Dulcitol & - & + & + & - & + & $+*$ \\
\hline i-Inositol & - & - & + & - & - & - \\
\hline Trehalose & - & + & + & + & + & + \\
\hline D-Tagatose & - & - & + & - & + & + \\
\hline L-Fucose & + & + & + & - & + & + \\
\hline 5-Ketogluconate & + & + & + & - & + & + \\
\hline
\end{tabular}

* Only seven of the eight strains were positive.

corresponds to the former 'sub-genus' I and contains human and animal pathogens, including those species listed in the Approved Lists by ranking them down to infrasubspecific serovars (International Journal of Systematic Bacteriology, 1985; Le Minor et al., 1986).

In 1987, Le Minor \& Popoff published a Request for an Opinion to designate Salmonella enterica sp. nov., nom rev. as the type and only species of the genus Salmonella (Le Minor \& Popoff, 1987; International Journal of Systematic Bacteriology, 1987). They intended to replace the species name $S$. choleraesuis with $S$. enterica because of nomenclatural confusion due to identity of the specific epithet choleraesuis with the serovar name Choleraesuis. Such replacement of the earliest legitimate specific epithet by another epithet is one of the reasons for which the name is illegitimate according to Rule $51 \mathrm{~b}(2)$. Rule $51 \mathrm{~b}(2)$ reads, 'If the author did not adopt for a binary or ternary combination the earliest legitimate generic name, specific epithet, or subspecific epithet available for the taxon with its particular circumscription, position, and rank.' $S$. enterica was originally proposed by Kauffmann \& Edwards (1952) to replace the 
species name 'Salmonella kauffmannii' and was cited in Index Bergeyana as an illegitimate name according to Rule $24 \mathrm{~b}$ of the Code (International Committee on Bacteriological Nomenclature, 1958).

The Judicial Commission of the International Committee of Systematic Bacteriology did not award the Opinion requested by Le Minor \& Popoff (1987) to designate $S$. enterica sp. nov. as the type and only species of the genus Salmonella (Wayne, 1994). Le Minor et al. (1982) proposed placing pathogenic Salmonella serovars in $S$. choleraesuis subsp. choleraesuis. Thus, S. paratyphi became $S$. choleraesuis subsp. choleraesuis serovar Paratyphi A. Concerning the rejection of names, an item was added to Rule 56a(5) in the Code (Lapage et al., 1992). It reads, 'A perilous name (nomen periculosum), i.e. a name whose application is likely to lead to accidents endangering health or life or both or of serious economic consequences.' Because $S$. paratyphi is a contagious organism causing typhoid-fever-like disease (paratyphoid fever) in humans, Rule 56a(5) must be applicable to the inclusion of $S$. paratyphi in $S$. choleraesuis subsp. choleraesuis as one of the serovars, because the organism is widely recognized as contagious and virulent and cited in the list of Class 3 pathogens. At the end of Rule 56a(5) (Lapage et al., 1975), Note 1 states that 'If the Judicial Commission recognizes a high order of risk to health, or of serious economic consequences, an Opinion may be issued that the taxon be maintained as a separate nomenspecies, without prejudice to the recognition or acceptance of its genetic relatedness to another taxon.'

From the reasons described above, we herein propose to raise Salmonella choleraesuis subsp. choleraesuis serovar Paratyphi A to species status and request that this organism be designated as Salmonella paratyphi sp. nov., nom. rev. and conserve the specific epithet paratyphi in the binary combination Salmonella paratyphi.

\section{Description of Salmonella paratyphi (Kayser 1902) sp. nov., nom. rev.}

Salmonella paratyphi (pa.ra.ty'phi. Gr. prep. para alongside; Gr. n. typhus a stupor; M.L. n. paratyphi of paratyphoid).

Gram-negative, motile with peritrichous flagella and fermentative rods, consistent with the definition of the genus Salmonella as described by Le Minor \& Rohde (1974) and Le Minor (1984). Strains of S. paratyphi, however, characteristically fail to utilize citrate as sole carbon source, to produce black iron sulfide compound and have weakly positive or negative lysine decarboxylase activity (Smith, 1948). Antigenic formula is $1,2,12: \mathrm{a}:[1,5]$. Strain NCTC $5702^{\mathrm{T}}(=\mathrm{KI}$ $\left.1015^{\mathrm{T}}\right)$ is designated as the type strain for the species. The antigenic formula for this strain is 1,2,12:a: - . DNA-DNA similarity values for the type strain to other Salmonella species at different stringency levels
(Ezaki et al., 1989) are listed in Table 1 and differential biochemical and serological characteristics of this species are indicated in Table 2.

Among more than 2000 serovars of S. choleraesuis subsp. choleraesuis, two serovars carry the name Paratyphi: serovars Paratyphi B and Paratyphi C. They are not causative agents of typhoid or paratyphoid fever. Therefore, their name might cause confusion to medical microbiologists. However, serovar Paratyphi B is now called serovar Schottmuelleri. Serovar Paratyphi C was once called serovar Hirschfeldii (Le Minor \& Rohde, 1974). If enterobacteriologists promote the use of serovar names Schottmuelleri and Hirschfeldii for serovars Paratyphi B and Paratyphi C, respectively, confusion will be avoided.

\section{References}

Brion, A. \& Kayser, H. (1902). Ueber eine Erkrankung mit dem Befund eines typhus-aehnlichen Bakteriums im Blute (Paratyphus). Muench Med Wochenschr 49, 611-615.

Buchanan, R. E., Holt, J. G. \& Lessel, E. F. (1966). Index Bergeyana. Baltimore: Williams \& Wilkins.

Castellani, A. \& Chalmers. A. S. (1919). Manual of Tropical Medicine, 3rd edn. New York: William Wood \& Co.

Ezaki, T., Hashimoto, Y. \& Yabuuchi, E. (1989). Fluorometric deoxyribonucleic acid-deoxyribonucleic acid hybridization in microdilution wells as an alternative to membrane filter hybridization in which radioisotopes are used to determine genetic relatedness among bacterial strains. Int J Syst Bacteriol 39, 224-229.

International Committee on Bacteriological Nomenclature (1958). International Code of Nomenclature of Bacteria and Viruses. Ames, IA: Iowa State University Press.

International Journal of Systematic Bacteriology (1985). Validation of the publication of new names and new combinations previously effectively published outside the IJSB, List No. 18. Int J Syst Bacteriol 35, 375-376.

International Journal of Systematic Bacteriology (1987). Validation of the publication of new names and new combinations previously effectively published outside the IJSB, List No. 23. Int J Syst Bacteriol 37, 179-180.

Judicial Commission (1954). International Committee on Systematic Bacteriology. Opinion 4 (revised). Rejection of the generic name Bacterium. Int Bull Bacteriol Nomencl Taxon 4, $141-142$.

Kauffmann, F. (1960). Two biochemical sub-divisions of the genus Salmonella. Acta Pathol Microbiol Scand 49, 393-396.

Kauffmann, F. (1963). Zur Differential diagnose der Salmonella Sub-genera I, II, und III. Acta Pathol Microbiol Scand 58, 109-113.

Kauffmann, F. (1966). Das Salmonella Sub-genus IV. Ann Immunol Hung 9, 77-80.

Kauffmann, F. \& Edwards, P. R. (1952). Classification and nomenclature of Enterobacteriaceae. Int Bull Bacteriol Nomencl Taxon 2, 2-8.

Kayser, H. (1902). Das Wachstum der zwischen Bacterium typhi und coli stehenden Spaltpilze auf dem v. DrigalskiConradi'schen Agarboden. Zentbl Bakteriol Abt 1 Orig 31, 426-429. 
Kelterborn, E. (1967). Salmonella paratyphi-A = 1,2,12:a: - In Salmonella Species, p. 305. Edited by E. Kelterborn. Leipzig: Hirzel.

Lapage, S. P., Sneath, P. H. A., Lessel, E. F., Skerman, V. B. D. Seeliger, H. P. R. \& Clark, W. A. (editors) (1975). International Code of Nomenclature of Bacteria (1975 Revision). Washington, DC: American Society for Microbiology.

Lapage, S. P., Sneath, P. H. A., Lessel, E. F., Skerman, V. B. D., Seeliger, H. P. R. \& Clark, W. A. (editors) (1992). International Code of Nomenclature of Bacteria (1990 Revision). Bacteriological Code. Washington, DC: American Society for Microbiology.

Le Minor, L. (1984). Salmonella. In Bergey's Manual of Systematic Bacteriology, vol. 1, pp. 427-458. Edited by N. R. Krieg \& J. G. Holt. Baltimore: Williams \& Wilkins.

Le Minor, L. \& Popoff, M. Y. (1982). Proposition pour une nomenclature des Salmonella. Ann Microbiol (Inst Pasteur) 133B, 245-254.

Le Minor, L. \& Popoff, M. Y. (1987). Request for an Opinion. Designation of Salmonella enterica sp. nov., nom. rev., as the type and only species of the genus Salmonella. Int $J$ Syst Bacteriol 37, 465-468.
Le Minor, L. \& Rohde, R. (1974). Salmonella. In Bergey's Manual of Determinative Bacteriology, 8th edn, pp. 298-318. Edited by R. E. Buchanan \& N. E. Gibbons. Baltimore: Williams \& Wilkins.

Le Minor, L., Veron, M. \& Popoff, M. Y. (1982). Taxonomie des Salmonella. Ann Microbiol (Inst Pasteur) 133B, 223-243.

Le Minor, L., Popoff, M. Y., Laurent, B. \& Hermant, D. (1986). Individualization d'une septieme sous-espèce de Salmonella: $S$. choleraesuis subsp. indica subsp. nov. Ann Microbiol (Inst Pasteur) 137B, 211-217.

Skerman, V. B. D., McGowan, V. \& Sneath, P. H. A. (1980). Approved lists of bacterial names. Int $J$ Syst Bacteriol 30, 225-420.

Smith, F. (1948). Salmonella paratyphi (Kayser) Castellani and Chalmers. In Bergey's Manual of Determinative Bacteriology, 6th edn, p. 501. Edited by R. S. Breed, E. G. D. Murray \& A. P. Hitchens. Baltimore: Williams \& Wilkins.

Wayne, L. G. (1994). Actions of the Judicial Commission of the International Committee on Systematic Bacteriology on Requests for Opinions published between January 1985 and July 1993. Int J Syst Bacteriol 44, 177-178. 